\title{
Cross-nationalizing the History of Industrial Hazard
}

\author{
CHRISTOPHER C SELLERS*
}

Over the summer months of 2007, Mattel Inc., the world's largest toy-maker, recalled some twenty million toys, nearly three million of them because of lead-contaminated paint. The recall mushroomed into an international event. In Germany, regulators pulled some one million toys from the shelves, in Britain and Ireland, two million; countries from Malaysia and Bahrain joined the toy returns. In just one of the incriminated Chinese factories, some eighty-three different kinds of toys may have been painted with lead pigment: Thomas the Tank engine, Dora the Explorer, Sesame Street characters of Cookie Monster, Elmo and Big Bird, as well as "Sarge" and other figures based on the Disney movie Cars. Suddenly, this toxic metal, along with carbon monoxide the world's oldest recognized industrial hazard, took the western world by surprise. Despite widespread assumptions that we were safe from its clutches, a whole new vein of lead had turned up, running into our department stores, homes, and perhaps also our children. ${ }^{1}$

The episode graphically exposed how we in western nations now frame the hazards our industries may impose upon us. US media coverage was split between blaming and exonerating Mattel's executives but, more uniformly, construed this as a crisis for American consumers. The furore revolved almost entirely around the malfeasance of our own corporations and regulatory agencies, or around the evil and neglectful Chinese. Coverage did extend to the industrial pollution produced by China's quarter century of economic boom, but the insides of its factories were another matter. A report by a US-based group, the China Labor Watch, about the "brutal conditions" in Chinese toy factories, was released at what might seem the perfect time, a week after the lead recall story broke. But the momentary upsurge in coverage then faded, as reporters stuck to Mattel's, and their nations', efforts to monitor what Chinese factories made. ${ }^{2}$

CC Christopher C Sellers 2010

* Christopher C Sellers, MD, PhD, Department of History, State University of New York at Stony Brook, Stony Brook, NY 11794-4348, USA; e-mail: csellers@notes.cc.sunysb.edu

1 'Millions of Mattel toys recalled in Europe', Germany/UK (14 Aug. 2007) accessed 23 Aug. 2007 at http://tvscripts.edt.reuters.com/2007-0814/1aa2f5a9.html; 'Parents urged to check homes as 2 million unsafe toys are recalled', Timesonline (15 Aug. 2007) accessed 23 Aug. 2007 at http://www.timesonline.co.uk/to1/news/uk/ article2260555.ece; 'Mattel Inc. toys in Asia recalled on concerns over lead in paint', International Herald Tribune/Business (3 Aug. 2007) accessed 30 May 2008 at http://www.iht.com/articles/ap/2007/08/ 03/business/AS-FIN-Asia-Toy-Recal.php.

\footnotetext{
${ }^{2}$ China Labor Watch, 'Investigation on toy suppliers in China; workers are still suffering', (21 Aug. 2007) accessed 30 May 2008 at http://www.chinalaborwatch.org/ 20070821eighttoy.htm; 'China accused of abusing workers', CNN.com homepage (21 Aug. 2007) accessed 31 May 2008 at http://edition.cnn. com/video/\#/video/world/2007/ 08/23/snow. china.toy.woes.cnn; David Barboza, 'U.S. group accuses Chinese factories of labor abuses', New York Times/World Business (22 Aug. 2007) accessed 31 May 2008 at http://www.nytimes. com/2007/08/22/business/worldbusiness/22factory. html?_=1\&ref=business \& oref=slogin; despite ample follow-up on other aspects of the toy recall, the New York Times reporter did not return to this issue until early 2008, when China was in the process of revamping its own labour laws.
} 


\section{Christopher C Sellers}

Media priorities were revealing of how we in the developed nations, perhaps especially in America, now have quite a different attitude towards industrial hazards than we did a century ago. At that time, what public discussions there were of lead poisoning mainly concerned its effects on workers. But in this first decade of the twenty-first century, the United States has become so dependent on developing nations for manufacturing that the vast majority of goods we buy have been made elsewhere. A full 65 per cent of Mattel's products are made in China; as are up to 80 per cent of all toys sold in the US. This degree of dependence has evolved in the wake of new regulatory regimes in America and Europe, based on ever more precautionary principles. But while the United States has effectively restricted or abolished the most dangerous usages of many industrial materials and processes within its own borders, not all other nations have followed suit. ${ }^{3}$ Capitalism has thereby been busy, making us westerners ever more clueless about the industrial hazards that our own and other corporations foist upon the rest of the world, in supplying the products for our way of life.

A century and a half ago, when Karl Marx coined the notion of commodity fetishism, he was referring to a phenomenon that occurred inside a given nation. For many of us today, the spell of the commodity, shiny and colourful in its appearance on store shelves, continues to obscure the social relations of the workplace, as Marx would have it, including the labouring hands that actually made it. ${ }^{4}$ How much more powerful the spell of the commodity has become in our own time and place, when most manufacturing happens in a foreign land, when Americans' and Europeans' encounters with the factory and its work are becoming so few and far between. We have heard much about how globalization has collapsed distance, linking people from different nations via, among other ways, global supply chains. Here is one area where you do not need to be a Marxist to see that linkage enables attitudes not so much of connection as of indifference. Undertaking the task of making commodities for us, these distant places shoulder a scale and variety of hazards that our own "progress" has made ever more difficult for us to imagine.

For all the work they have done over the past twenty years in uncovering the history of these hazards, historians of health and other areas have thus far provided relatively few insights into this contemporary dilemma. We have learned about the history of industrial hazards in a widening array of nations, yet an obstacle persists. Almost all our studies tend to take the enshrinement of health and/or environmental protection in a single locale or nation as the end of the story. Inadvertently, we thereby project a universality onto what are, as this crisis of leaded toys reminds us, our own nation-bound experiences. This paper explores ways in which we may give greater heed to those cross-national and mutual transformations that have brought us to this juncture. I argue for a more deliberate inclusion of multiple scales in our historical projects, from the local and national to the international or global. Such

\footnotetext{
3 'Mattel CEO defends toy manufacturing operations in China', Cox Newspapers Washington Bureau (13 Sept. 2007) accessed 30 May 2008 at http://www.coxwashington.com/hp/content/ reporters/stories/2007/09/1; Nancy Langston, 'The retreat from precaution: regulating diethylstilbestrol (DES), endocrine disruptors, and environmental health', Environ. Hist., 2008, 13 (1): 41-65; David Rosner and Gerald Markowitz, 'Industry challenges to the principles of prevention in public health: the
}

precautionary principle in historical perspective', Public Health Reports, 2002, 117: 501-12; Sonja Boehmer-Christiansen, 'The precautionary principle in Germany - enabling government', in Timothy O'Riordan and James Cameron (eds), Interpreting the precautionary principle, London, Earthscan, 1994.

${ }^{4}$ Karl Marx, Capital, ed. Frederick Engels, 3 vols, New York, International Publishers, 1967 (lst German ed., 1867), vol. 1, pp. 71-83. 
conscious alternation creates a greater awareness of those transnational connections-as well as disconnections - that prevailed at a given time and place.

Once we start to reflect more self-consciously on these differences of scale, to analyse their historical specificity and interdependence, further methodological dilemmas present themselves. Tools that have been around for a while-the traditions of comparative case studies, world-systems theory, global history, and the history of international institutionsneed better reconciling with the largely more localized insights of the last decades of social and cultural history. Among the contrasts, these traditions of sweeping and macro-historical views have often leaned more on material objects and dynamics, whether of infection or economics, while the social and cultural history of the last twenty years of scholarship has concentrated more on those many groups, perceptions, and conflicts shaping the history of health and environment in a single place.

I suggest we may better reconcile what have heretofore seemed diametrically opposed terms of historical analysis by considering a toxin's variable and evolving materiality. The "stuff" or nature of lead is, after all, what links today's Chinese lead workers with the toxic toys discovered on our store shelves. This example also suggests how biases of perception, rooted in our own geographic and disciplinary standpoints, have subtly steered our scholarship away from differences. Now, as in the past, a real but not fully recognized danger may be lurking in distant places. Confining ourselves to social or cultural analysis alone impedes our ability to address some key dimensions of difference, and their moral implications. We need to embrace, more or less forthrightly, what today's scientists now know about the impact of lead on human bodies and environments.

By consciously juxtaposing lead's contemporary and historical manifestations, we open the door to a more robust interdisciplinary holism, a fuller integration of natural scientific and medical insights with those from the social sciences and humanities. We also gain new analytical leverage for comparing and interpreting the great variety of views of a toxin such as lead across time and place. We can, by way of illustration, situate international perspectives, from those of today to that of the early International Labour Organization (ILO), alongside national regulatory projects of countries as different as the United States and China or Mexico, and local perspectives afforded, for instance, by looking at the history of a single lead smelter in El Paso, on the US-Mexico border. The historical study of transnational interactions thereby becomes more manageable. We can begin to address why and how a single industrial hazard has acquired such different manifestations and meanings in Mexico and China as opposed to the United States.

\section{The Multi-scalar and the Material: Historiographic Trends and Precedents}

Nowhere have the contrasts between global or transnational and national or local approaches been more marked than in the historiography of industrial hazards itself. When Henry Sigerist and Ludwig Teleky wrote about workplace hazards in the middle of the twentieth century, their analyses leaped with relative ease from one nation's experience to another's. Their inclusion of so many different nations' experiences side by side hinged on largely unscrutinized assumptions about the cross-national uniformity of industrialization, its hazards, and their prevention. Ignoring hazards outside the workplace, they homed in 
on two specific aspects of the hazards within it: detection and regulation. Both authors conceptualized this "progress" mainly as the passage of the right laws, creating rules and agencies that empowered experts, who accomplished what was needed. ${ }^{5}$ The revival of the historiography of industrial hazards from the 1980s greatly complicated this earlier intellectual legacy of nation-hopping. The methodology of social history revealed the wide range of other groups that have had an influential role in determining the approach to occupational hazards at a given place and time. Apart from doctors and hygienic experts, we have learned that the willingness of managers or owners, technological change, and especially the insistence or protest of workers, whether unionized or not, may all have an impact on the dangers afflicting a particular workplace. Within any nation or industry, questions of recognition and regulation are so fraught with struggles between groups that "progress" itself looks more contingent than straightforward, a matter of contention. ${ }^{6}$

Environmental history has complicated matters still further by broaching those many other hazards and conflicts that industrial production may cause. Factories may contaminate nearby neighbourhoods or, via air or rivers, more distant regions. Still further afield, their toxins may turn up in consumer goods, from paint to apples. ${ }^{7}$ More or less tacitly, these insights, in parallel with those in the social history of occupational hazards, have become possible through what, in comparison with the studies of Sigerist or Teleky, looks like a certain confinement of geographic scope. It is by the careful unpacking of national and, below that, of local circumstances that we have learned about the myriad groups and complex politics leading to the recognition of black lung, or the impact of a factory or refinery on neighbouring communities. ${ }^{8}$ Such insights, if we are to absorb them, have made it difficult

\footnotetext{
${ }^{5}$ Henry E Sigerist, 'Historical background of industrial and occupational diseases', Bull. N. Y. Acad. Med., 1936, 12 (11): 597-609; Ludwig Teleky, History of factory and mine hygiene, New York, Columbia University Press, 1948; George Rosen, The history of miners' diseases, a medical and social interpretation, New York, Schuman's, 1943.

${ }^{6}$ Social history work in English began with two collections of the mid-1980s, Paul Weindling (ed.), The social history of occupational health, London and Dover, NH, Croom Helm, 1985; David Rosner and Gerald Markowitz (eds), Dying for work: essays on the history of workers' safety and health in twentieth century America, Bloomington, Indiana University Press, 1987. More recent studies include Arthur McIvor and Ronald Johnston, 'Medical knowledge and the worker: occupational lung diseases in the United Kingdom, c.1920-1975', Labor: Studies in Working Class History of the Americas, 2005, 2 (4): 63-86; Mark W Bufton and Joseph Melling, "“A mere matter of rock": organized labour, scientific evidence and British government schemes for compensation of silicosis and pneumoniosis among coal miners, 1926-1940', Med. Hist., 2005, 49 (2): 155-78; Angela Vergara, 'The recognition of silicosis: labor unions and physicians in the Chilean copper industry, 1930s-1960s', Bull. Hist. Med., 2005, 79 (4): 723-48.

${ }^{7}$ The literature has become voluminous but recent work is well-illustrated in a recent special issue of the
}

journal Environmental History: Jody A Roberts and Nancy Langston, 'Toxic bodies/toxic environments: an interdisciplinary forum', Environ. Hist., 2008, 13 (4): 629-35, accessed 9 May 2009 at http://www.historycooperative.org.libproxy. cc.stonybrook.edu/journals/eh/13.4/roberts.html; Stephen Mosley, 'Common ground: integrating social and environmental history', J. Soc. Hist., 2006, 39 (3): 915-33; Joy Parr, 'Smells like?: sources of uncertainty in the history of the Great Lakes environment', Environ. Hist., 2006, 11 (2): 269-99; Linda Nash, 'Purity and danger: historical reflections on the regulation of environmental pollutants', Environ. Hist., 2008, 13 (4): 651-8.

${ }^{8}$ Alan Derickson, Black lung: anatomy of a public health disaster, Ithaca, Cornell University Press, 1998; Arthur McIvor and Ronald Johnston, Miners' lung: a history of dust disease in British coal mining, Aldershot and Burlington, VT, Ashgate, 2007; Andrew Hurley, Environmental inequalities: class, race, and industrial pollution in Gary, Indiana, 1945-1980, Chapel Hill, University of North Carolina Press, 1995; Barbara L Allen, Uneasy alchemy: citizens and experts in Louisiana's chemical corridor disputes, Cambridge, MA, MIT Press, 2003; Gerald Markowitz and David Rosner, Deceit and denial: the deadly politics of industrial pollution, Berkeley, University of California Press, 2002. 
to return to those assumptions that enabled an earlier cross-nationalism in industrial hazard history.

A further complication has been the cultural turn of scholarship of the 1980s and 1990s history of science as well as medicine. At stake in the science or medicine of a specific time and place are not just social conflicts but cultural constructions, an expert discourse that mediates the realities of nature and the human body, and may itself dispense or exert power. Scholars in science studies laid the groundwork by urging, then largely by assuming, an agnosticism towards the natural objects named and debated by scientists, early on styled as a sociological "principle of symmetry". Across science studies (including the history of science and medicine), much cutting-edge work of the 1980s and 1990s shunned invocations of the material, whether natural or economical, as Popperian positivism. Struggles to carve out room and recognition for sociocultural insights fuelled the now-familiar debates over the social construction of science, or "science wars", of the 1990s. Whether more or less influenced by construction, historians of science and of medicine often subscribed to a rigorous historicism with similar implications: not to attend to material objects and influences until the doctors and scientists of an era recognized them. ${ }^{9}$

Partly to get beyond the stark position-taking of these debates, scholarship in science studies as well as in medical and science history has more recently gravitated towards questions of ontology, that branch of philosophy that deals with the experience and perception of objects in our world. Recognizing that more than just "ideas" are at risk in the historical trajectories of medical and other sciences, scholars of technoscience now prefer to talk of "materiality": of how bodies_human or otherwise-have manifested themselves, or "mattered", in different ways in different places and times. Projects such as Lorraine Daston's edited volume on biographies of scientific objects and Ian Hacking's Historical ontology seek to reconcile the dynamic historicity of scientific objects with their solidity and durability for historical actors in a given time and place. This is a powerful insight, of great value to the historian of industrial hazard. Yet such an historian would hobble himor herself considerably by sticking, as Daston and Hacking do, to "objects or their effects which do not exist in any recognizable form until they are objects of scientific study". ${ }^{10} \mathrm{~A}$ troubling but enduring constant of industrial hazard history is that the hazards themselves, along with their victims, have often existed long before they were made the objects of formal scientific study. To make the most of an historical ontology approach, historians

\footnotetext{
${ }^{9}$ For two discussions of the various symmetry principles invoked in science studies, see Daniel Breslau, 'Sociology after humanism: a lesson from contemporary science studies', Sociological Theory, 2000, 18 (2): 289-307; Alex Preda, 'The turn to things: arguments for a sociological theory of things', Sociological Quarterly, 1999, 40 (2): 347-66.

${ }^{10}$ The phrase "matters" comes from Judith Butler, Bodies that matter: on the discursive limits of 'sex', New York and London, Routledge, 1993. I mean to invoke here an additional body of literature on historical ontology, coined by Ian Hacking, Historical ontology, Cambridge, MA, Harvard University Press, 2002 ("recognizable form", p. 11), which stresses a "materiality" defined through a variety of historic-cultural lenses and practices; Lorraine Daston
}

(ed.), Biographies of scientific objects, University of Chicago Press, 2000; Don Ihde and Evan Selinger (eds), Chasing technoscience: matrix for materiality, Bloomington, Indiana University Press, 2003; Christophe Lecuyer and David Brock, 'The materiality of microelectronics', History and Technology, 2006, 22 (3): 301-25; Alison Ravencroft, 'Coming to matter: the grounds of our embodied difference', Postcolonial Studies, 2007, 10 (3): 287-300; also Christopher Sellers, 'The artificial nature of fluoridated water: between nations, knowledge, and material flows', Osiris, 2nd series, Landscapes of exposure: knowledge and illness in modern environments, ed. Gregg Mitman, Michelle Murphy and Christopher Sellers, 2004, 19: 182-200. 


\section{Christopher C Sellers}

of industrial hazard would best seek ways of integrating its insights with the health and ecological, as well as economic, dynamics of the times, facets of history which today's sciences themselves may illuminate.

Easing the prospects for integration, over the last twenty years veins of inquiry more open to the "positivist" sciences have forged new understandings of the history of cross-national economic interchanges, and also, more socio-cultural approaches. Business historians like Alfred Chandler have charted the expansion of a single institution, the large corporation, across national boundaries. Others have looked more generally at the rise and spread of modern industries as well as technologies, and, in the case of the economic historian Jeffrey Williamson, at changing patterns of a globalization defined with refreshing rigour as a measurable degree of market integration between nations. A different tradition draws upon the world systems theory of Immanuel Wallerstein, as in the recent work of the historical sociologist Beverly Silver, who charts, correlates and seeks to explain the changing global distribution of particular industries over the nineteenth and twentieth centuries, and the movements and resistance they have stirred. Other sociologists as well as geographers have offered searching attention to the cross-national interchanges involved in globalizing transformations, from commodity and migration networks to cultural shifts in literature and art. Most influentially, the neo-Marxist David Harvey has offered provocative readings of the spatial dynamics through which political/economic and cultural change may connect. ${ }^{11}$

Especially useful for historians tackling the changing geography of industrial hazards is Harvey's notion of the "spatial fix". It offers a general term for what journalists like William Greider in the 1990s often summed up as a "race to the bottom": once technologies of production become portable, producers seek out the cheapest and least protected or resistant labour and locales. This "race" itself deserves a great deal more study for how it may, as Greider suggests, have spurred a transfer of manufacturing and mining hazards to the developing world. Labour historians such as Jefferson Cowie in Capital moves offered an early compelling model of how study of this "race" may combine a transnational scope with the social historian's localist approach, by following the successive factory openings of a single company (RCA) from Newark and Indiana across the US border into Ciudad Juárez, Mexico. ${ }^{12}$ Unfortunately, labour historians of

\footnotetext{
${ }^{11}$ Alfred D Chandler Jr, Scale and scope: the dynamics of industrial capitalism, Cambridge, MA, Belknap Press of Harvard University Press, 1994; Kevin H O'Rourke and Jeffrey G Williamson, Globalization and history: the evolution of a nineteenth-century Atlantic economy, Cambridge, MA, MIT Press, 2001; Michael D Bordo, Alan M Taylor and Jeffrey G Williamson (eds), Globalization in historical perspective, University of Chicago Press, 2005; Immanuel Wallerstein, World-systems analysis: an introduction, Durham, Duke University Press, 2004; Beverly J Silver, Forces of labor: workers' movements and globalization since 1870, Cambridge University Press, 2002; Andrew Herod, Labor geographies: workers and the landscapes of capitalism, New York, Guilford Press, 2001;
}

\author{
David Harvey, The condition of postmodernity: an \\ enquiry into the origins of cultural change, reprint, \\ Oxford and Cambridge, MA, Wiley-Blackwell, 1990; \\ idem, Justice, nature and the geography of difference, \\ Malden, Wiley-Blackwell, 1997; idem, A brief history \\ of neoliberalism, Oxford University Press, 2005. \\ ${ }^{12}$ David Harvey, 'The spatial fix: Hegel, Von \\ Thunen, and Marx', Antipode, 1981, 13 (3): \\ 1-12, accessed 9 May 2009 at DOI:10.1111/ \\ j.1467-8330.1981.tb00312.x; William Greider, One \\ world, ready or not: the manic logic of global \\ capitalism, New York, Simon \& Schuster, 1997; \\ Jefferson R Cowie, Capital moves: RCA's \\ seventy-year quest for cheap labor, Ithaca, NY, \\ Cornell University Press, 1999); Silver, op. cit., \\ note 11 above.
}




\section{Cross-nationalizing the History of Industrial Hazard}

this "race to the bottom" from Silver to Cowie have little to say about any resulting hazards.

On this front, environmental history, long invested in an ecological materialism and recently inclined towards both cross-national and sociocultural methods, has offered further precedents and tools with which to work. Since its consolidation over the 1980s starting especially in the United States, this field has appealed, more or less, to "ecology", based on findings and methods of contemporary sciences, as a basis for writing "the role and place of nature in human history". ${ }^{13}$ Most environmental historians continue to adopt national and especially local sites for their projects, but over the 1990s, new scalar alternatives emerged. Some, such as Richard Grove, tackled the environmental history of colonial empires, while others, such as John McNeill, pursued a global environmental history, in his case, of twentieth-century transformations, industrial and otherwise. More in tune with the social historian's customary scale, a few environmental historians have also now composed studies that, without being either global or comparative in conception, are thoroughly transnational analyses of the interchange between select nations. Ian Tyrells' True gardens of the gods, by concentrating on the biotic interchange between two specific places, California and Australia, captures a contingency, and a social as well as an ecological complexity much closer to that of social history. Through a focus on single commodities, scholars such as John Soluri (bananas) and Jennifer Anderson (mahogany) have honed ways of studying those cross-national flows of funds, corporations, and technology, as well as local transformations that have connected the US with developing nations in Central America and the Caribbean. ${ }^{14}$

As some environmental historians have absorbed insights from cultural history and the history of science and medicine, finding common ground with the latter's "materiality" agenda, they have engaged more and more with issues of human and public health. By 2005, Richard White was declaring a "cultural turn" in environmental history, a receptiveness that was closely tied to this field's growing appreciation of the importance, and historicity, of human body-environment relations. Work, from that of Conevery Bolton Valenčius to that of Linda Nash and Gregg Mitman, has seamlessly blended a close attention to the history of on-the-ground ecological change to a deep appreciation of how fundamentally a society's categories and understandings of health and environment can also be transformed. Drawing and building upon recent transnational scholarship in medical history, especially by historians of colonial medicine such as Warwick Anderson and Mark Harrison, this convergent eclecticism of methods has opened much fruitful terrain, an intellectual borderland between environmental history, medical history, and the history of science. Historians of science and of medicine have further facilitated this approach by integrating material methods with a more familiar socio-cultural repertoire. For instance, recent studies of transnational flows

\footnotetext{
${ }^{13}$ Donald Worster, 'Transformations of the earth: toward an agroecological perspective in history', $J$. Am. Hist., 1990, 76: 1087-1106, p. 1089.

14 'Roundtable on environmental history', J. Am. Hist., 1990, 76:1087-147; J R McNeill, Something new under the sun: an environmental history of the twentieth-century world, New York, W W Norton, 2000; Ian Tyrrell, True gardens of
}

the gods: Californian-Australian environmental reform, 1860-1930, University of California Press, 1999; John Soluri, Banana cultures: agriculture, consumption, and environmental change in Honduras and the United States, Austin, University of Texas Press, 2005; Jennifer L Anderson, 'Nature's currency: the Atlantic mahogany trade, 1720-1830', PhD dissertation, New York University, 2007. 


\section{Christopher C Sellers}

of knowledge from Londa Schiebinger to Harold Cook have emphasized their ties to the movements of trade and commerce. ${ }^{15}$

Work and its hazards have provided much topical and thematic fodder for these convergences. In the history of industrial hazard, further investigation is needed of the different ways in which toxins and their effects have been viewed across times and places other than our own; yet strict nominalism and historicism can take us only so far into these differences. In particular, they cannot tell us much about where and when people may remain unaware, or only partly aware, of actual contemporaneous effects and pathology, or else have apprehended these, but in ways radically different from our own. By the same token, of course, a strictly ecological or epidemiological approach tells us little about such crucial issues as the evolution of hazard awareness and understanding, the sensory and cognitive experience of pollution, or the power struggles that could result. My point is this: any approach that remains too exclusively culturalist or materialist will in the end marginalize burning questions in the history of an industrial toxin such as lead.

Not so paradoxically, then, some privileging of today's scientific consensus about the nature of lead and its physiological effects may well be necessary in order more fully to discern the variety of ways in which an industrial hazard has "mattered" across place and time. Use of this knowledge helps us decipher which societies and groups have grappled with lead, and where we might expect its effects to register with scientists and doctors. Such extrapolations enable us better to study experiences beyond established scientific and medical communities, among those who might or might not have known it as "lead", or treated it as toxic. In particular, such extrapolations may provide important platforms for extending the historical study of industrial hazards to the developing world. As we seek to place the experiences with lead in different nations alongside one another, across a divide as deep and complex as that between developed and developing nations, it is especially important to delineate differences not just in political economy or culture but in concrete contacts with lead and its effects. As a starting point, rather than a symmetric agnosticism towards scientific claims about exposure, I suggest we make a conscious effort to assess historical exposures and their differences: a principle, instead, of environmental symmetry. Situating actual exposures to lead as experienced and understood in today's United States or Great Britain, against those in other places and times, can offer vital groundwork for understanding that the effects of this toxin may be apprehended in ways quite different from our own.

\footnotetext{
${ }^{15}$ Richard White, 'From wilderness to hybrid landscapes: the cultural turn in environmental history', Historian, 2004, 66 (3): 557-64; Conevery Bolton Valenčius, The health of the country: how American settlers understood themselves and their land, New York, Basic Books, 2002; Linda Lorraine Nash, Inescapable ecologies: a history of environment, disease, and knowledge, Berkeley, University of California Press, 2006; Gregg Mitman, Breathing space: how allergies shape our lives and landscapes, New Haven, Yale University Press, 2007; Roberts and Langston, op. cit., note 7 above; Mark Harrison, Climates and constitutions: health, race, environment and British imperialism in India, 1600-1850, Oxford University Press, 2002; Pati Biswamoy and
}

Mark Harrison (eds), Health, medicine and empire: perspectives on colonial India, Hyderabad, Orient Longman, 2006; Londa Schiebinger, Plants and empire: colonial bioprospecting in the Atlantic world, Harvard University Press, 2007; Londa Schiebinger and Claudia Swan (eds), Colonial botany: science, commerce, and politics in the early modern world, Philadelphia, University of Pennsylvania Press, 2007; Harold J Cook, Matters of exchange: commerce, medicine, and science in the Dutch golden age, New Haven, Yale University Press, 2008; Mitman, Murphy and Sellers (eds), op. cit., note 10 above; Christopher Sellers, 'Thoreau's body: towards an embodied environmental history', Environ. Hist., 1999, 4 (4): 486-514. 


\section{Up and Down the Scales of Lead's Present}

A principle of environmental symmetry can aid in understanding our own supra-national present, as well as the past. It opens a common ground between the socio-cultural history of industrial hazards and those global approaches to hazard history forged by scientists themselves, such as Clair Patterson and Jerome Nriagu in the case of lead. Human manipulations of the metal over the last two or three hundred years have spurred a lengthy episode of exposures that are much higher than those throughout humans' longer ecological and evolutionary history. ${ }^{16}$ Such a sweeping perspective flattens out the cross-national diversity that those toxic toys reveal at the heart of today's environmental dilemmas, and thereby offers only a limited analytic purchase on changing cross-national patterns not just of lead exposure but of its control, and the political, economic and cultural differences that make this control possible. In making a comparison between nations of industrial as well as medicoregulatory contentions with lead, medical historians would do well to use not only a global perspective, but also but one that takes into account the effects in particular localities. By alternating our range from the global to the national and all the way down to local factories and their surroundings, we can better flesh out those parallel, evolving fusions of culture and nature that comprise lead's twenty-first century present, as well as its twentieth-century past.

We may, for instance, assume an ecological or environmental symmetry to the lead now unexpectedly headed our way on Chinese toys. It suggests that this lead paint has already taken its toll elsewhere, not just on the muscles and brains of China's children but of its workers. Such hazards are part of the reason ILO and WHO officials estimated a global burden of some 1.1 million deaths from work-related disease and injury alone in 1999, roughly the same as from malaria. They project these numbers will rise over the first half of the twenty-first century. ${ }^{17} \mathrm{~A}$ chief reason cited for this projection is a continued "race to the bottom". Corporations, so the story goes, have been hunting not just for the cheapest labour, but for hazard havens, where dangerous materials and processes are tolerated. ${ }^{18}$ One advantage of following this process, using lead as a kind of tracer, is that it allows us to consider impacts that have gone largely unnoticed. When we move towards a fuller fleshing out of the finger of lead of our own time, we find it points not just to China but back at us, the better off of the developed world. We have forged our own, quite different relationships with lead: we use it still, even as our bodies register less of its presence around us.

For instance, America's public health triumph over lead is often illustrated through graphs that show declining blood lead levels over the late twentieth century, especially after lead was banned in gasoline. ${ }^{19}$ But if we step upward in scale, to look at world lead production

\footnotetext{
${ }^{16}$ Jerome O Nriagu, 'Global metal pollution', Environment, 1990, 32 (7): 6-11; Jerome O Nriagu, 'Tales told in lead', Science, 1998, 281 (5383), n.s.: 1622-3; McNeill, op. cit., note 14 above.

17 'The burden of occupational illness', Press Release WHO/31 (8 June 1999) accessed 6 March 2008 at www.who.int/inf-pr-1999/3n/pr99-31.html

${ }^{18}$ For instance, Anita Chan and Robert J S Ross, 'Racing to the bottom: international trade without a
}

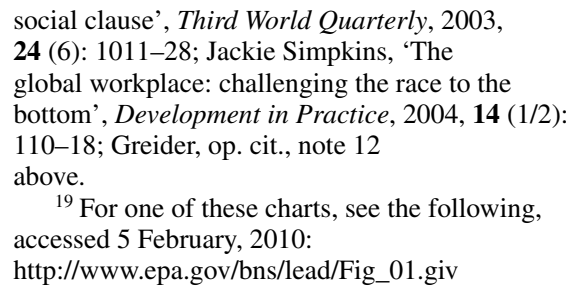




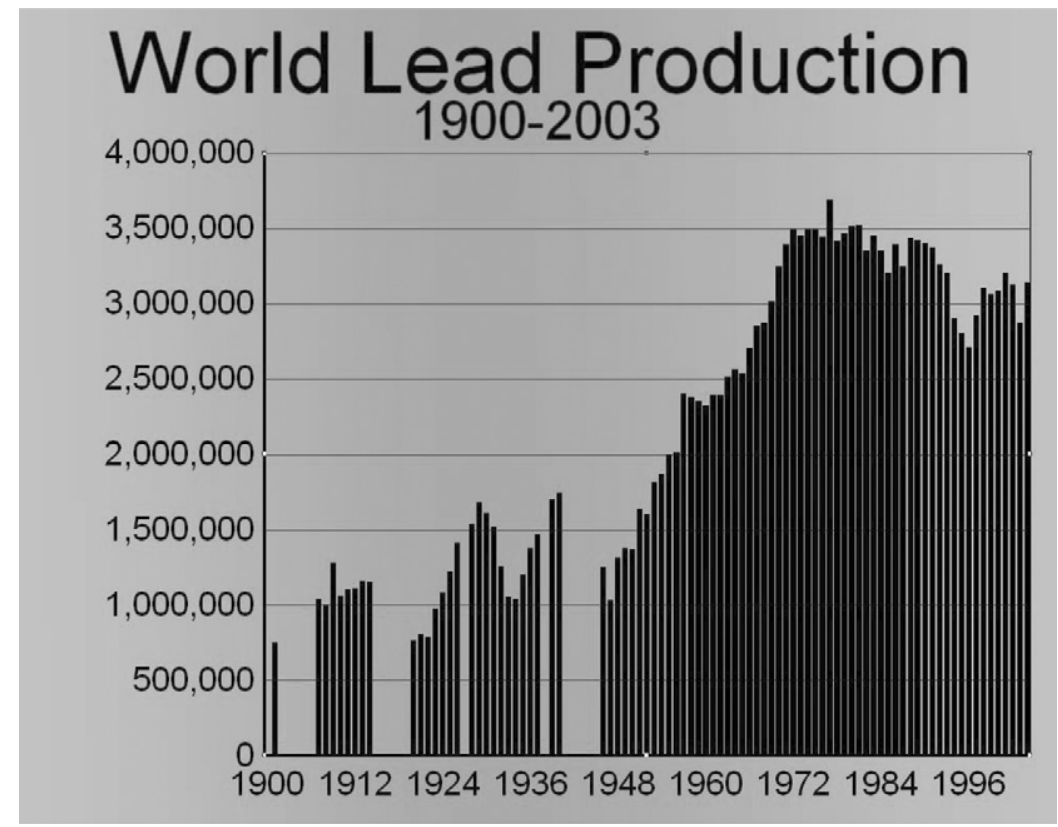

Figure 1: Lead production trends worldwide.

(Data source: B R Mitchell, International historical statistics, 3 vols, Basingstoke, Palgrave Macmillan, 2007.)

(Figure 1), a quite different picture emerges. Over the twentieth century, even after the recognition and regulation of the 1970s and 1980s, the amount of lead produced had, at best, only levelled off. That recent episode of lead-contaminated toys makes it easy to predict what might be happening if this is broken down by nation: Mexico's production has risen somewhat, but China's has sky-rocketed, especially over the last quarter century. What is surprising, though, is that lead production has also not declined in many of the most developed western nations such as the United States and the United Kingdom (Figure 2). Much of it comes through secondary production, that is, through the recycling of lead scrap, but the trend has still been level or upward.

Why? To explain, we first need to draw some distinctions between the realms and varieties of lead exposures involved. The chart of falling lead levels shows only the lead that was registered in the blood streams of those living in the United States. Its fall reflects, more than anything else, a ban on tetra-ethyl lead petrol, that most efficient means of making the lead Americans bought and consumed bio-available. Recognizing that the relatively tiny amounts of lead spewed into the atmosphere as car exhaust yielded such high bodily burdens, the US moved quickly from the 1970s onwards to ban this, as well as other consumer uses that made this toxin such a physiological, as well as an ecological, danger. But while such measures, along with workplace reductions, brought down blood levels of lead in the United States, they did little to prevent American usages of this toxin that did not make it bio-available, either in workplaces or in consumer products. And they did still less 


\section{Lead Production in Select Nations, 1931-2003}

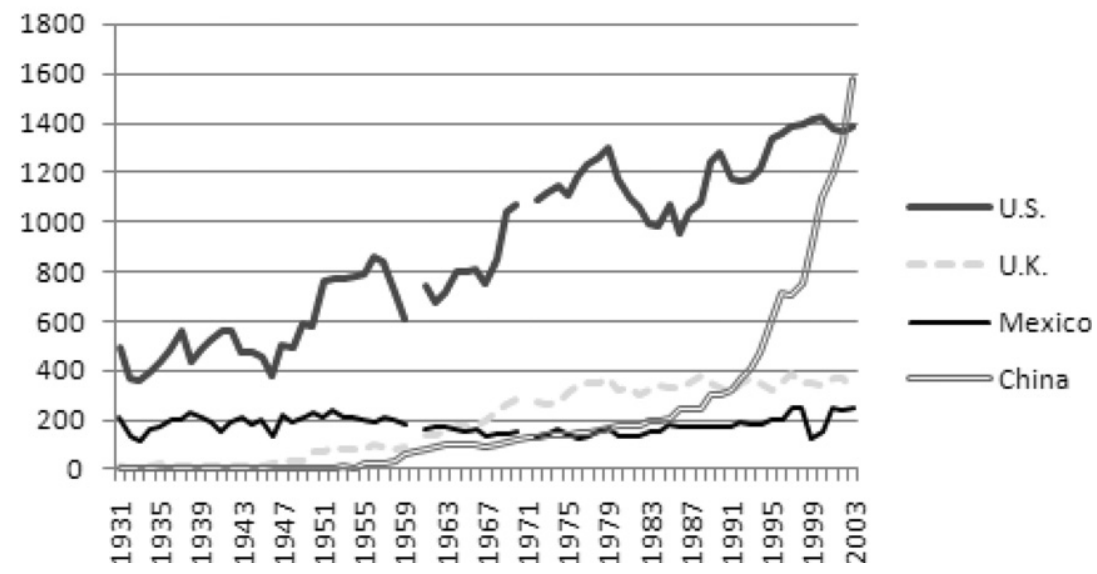

Figure 2: Lead production trends by nation.

(Data source: B R Mitchell, International historical statistics, 3 vols, Basingstoke, Palgrave Macmillan, 2007.)

to protect those beyond America's shores, either in the consumer markets of the developing world, or in its mines, smelters and production lines, where the commodities purchased by Americans were increasingly made.

As a result, consumers in the United States and other nations of the developed world have surrounded themselves with what may be a growing amount of lead. But it is "safe" lead, in products where it is tightly enclosed. Between 1973 and 1993, dissipative uses of lead, from petrol additives to ammunition to paint and similar products, shrank from 20 to 5 per cent of Americans' lead consumption. Meanwhile, electric soldering and especially batteries (accumulators) also contain lead, and the proportion of the lead in batteries consumed in the US leaped from 50 to 85 per cent over this same period. The cathode ray tubes in our television sets and computer screens, which contain as much as two kilograms of lead each, have added to the growth in lead usage. At the same time, all this lead is far from being safe for many outside the US, whether they are working or living where it is smelted and processed, or exposed to the toxin as a result of a blossoming international trade in electronic waste. $^{20}$

Americans' public health victory over lead reflected in those charts of declining blood lead levels has not come without costs. Even as Americans' and other westerners' lives depend on lead as much as ever, its presence in our environment has been carefully constructed, materially as well as socially, so that we do not give it another thought. Those contaminated toys from China may have surprised us, but we had already unconsciously become remote

\footnotetext{
${ }^{20}$ Marilyn B Biviano, Lorie A Wagner and Daniel E Sullivan, Total materials consumption: an estimation methodology and example using lead, a
}

materials flow analysis, US Geological Survey Circular No. 1183, Washington, DC, US Government Printing Office, 1999. 


\section{Christopher C Sellers}

consumers of the produce of Chinese and other developing-world mines and smelters. Yet we too easily lose sight of our dependence on, and complicity with, the continuing imposition of these hazards on victims elsewhere.

How might we frame and research historical projects in ways that enable more scrutiny of, perhaps even foreground, these relations and dependencies? A first step, as in many other new arenas of historical inquiry, is to sketch a preliminary periodization. Historians exploring new models for industrial hazard history have begun to distinguish two broad interconnecting phases over the twentieth century. It is only recently, from the 1960s onwards, that this new, more broadly environmental science and regulation, which removes bio-available lead from consumer products like petrol and paint, took hold in the United States. A preceding phase, roughly covering the first half of the century, was dominated by modes of knowing and regulating that, at least in the United States and other developed nations, concentrated far more on workplace exposures. The circulation of lead, its hazards, and their remedies were similarly cross-national in each of these eras. Hence, our exploration of the research possibilities will in each case involve a global overview, as well as a local study, of a single lead smelter poised between Mexico and the United States.

\section{Multiple Scales in a Past Time: The Early Twentieth-Century "Global"}

One problem with dividing history into periods needs early acknowledgement: the further back we go, the more we encounter difficulties with evidence. Although comparable historical statistics are now available for many nations' extractive and manufacturing industries, even such recent statistics as those available for the early twentieth century are fragmentary and difficult to compare. Nevertheless, transnational vantage points are available for tracking the lead industries in various nations, namely, the statistics compiled by the League of Nations. In its tracking of national efforts to recognize and regulate lead's dangers, a group like the International Labour Organization, founded in 1919 alongside the League of Nations, helps to illuminate these cross-national patterns in the regulation of industrial hazards. Such international institutions and their global perspectives deserve more attention from industrial hazard historians. In order to understand better the "global imagination as well as influence" of a group such as the ILO, to flesh out just what its perspective did and did not encompass, we need to scrutinize its constitution, meaning, and consequences not just within its Geneva headquarters, but also outside; i.e. the impact it had at various levels and locales around the world.

The ILO coalesced only after the production and consumption of lead by its chief supporting nations had undergone many decades of transformation, accompanied by rising scrutiny by health experts and the state. In the mostly European and developed nations out of which the ILO arose, private lead and other companies had turned to increasingly larger scale production, and new forms of labour organization — national unions- - had long since arisen. In its structure, the International Labour Organization reflected an historically and geographically specific vision of modern society. Democratic governance was assumed. A tripartite representation included national delegates from trade unions, employers and central governments. In stark contrast to later attitudes, the industrial workplace was imagined 


\section{Cross-nationalizing the History of Industrial Hazard}

to be the central stage where "social justice" was contested and dispensed. ${ }^{21}$ While a more recent understanding of lead has riveted on extra-workplace, environmental contamination, talk about lead in the early days of the ILO reflected just how thoroughly this organization confined its purview to worker hazards and the site of production itself.

The ILO deserves a great deal more attention from industrial hazard historians, starting with its work in passing "conventions" that it recommended be made law by all its member nations, thus instituting worldwide regulation. Initially, many of the recommendations addressed particular industrial dangers, faced especially by nations in the developed world. For instance, one of the ILO's first conventions, mentioned only in passing by many recent historians, was a 1921 ban on white lead pigments in interior paint. While today we might see here only a concern about consumer usage and the exposure of children, the documents indicate that the chief worries of ILO delegates were about adult painters, who were more likely to be poisoned by lead pigments when working indoors. Also characteristic was their reliance on a classic clinical presentation of lead poisoning, as one of the first three "occupational diseases" for which they recommended workers' compensation. We know relatively little, as yet, about how the ILO came to these and other recommendations, or about its "correspondence committee" of experts in industrial health and safety, which culled information from member states for ILO statements of existing knowledge and practice. Clearly, however, knowledge dissemination on this "most important subdivision of social medicine", in the view of its occupational health director Luigi Carozzi, was high on its agenda. Much of Carrozzi's early efforts concerned the production of an encyclopaedia, published in 1930, that was made available in English, French, and Spanish, and widely distributed. ${ }^{22}$

A strict historicism, conforming only to the lead hazards that the ILO and its experts saw at the time, yields many interesting questions, for which the organization's archives in Geneva, voluminous and nearly untapped, promises abundant answers. But we gain additional analytical leverage by recognizing important limitations in how this international agency conceived of an early twentieth-century flow of lead into human societies, environments, and bodies. What stands out, compared with today's concerns about lead, is just how little consideration the ILO devoted to contacts with lead outside the workplace. Everything else was considered "public health", an enterprise at this time largely centring on germs. The encyclopaedia, for instance, included an essay on 'Homework', and another on 'Food

\footnotetext{
${ }^{21}$ William Martin, 'The International Labour Organization', Proceedings of the Academy of Political Science in the City of New York, July 1926, 12 (1): 399-410; Markku Ruotsila, "“The Great Charter for the Liberty of the Workingman": labour, liberals and the creation of the ILO', Labour History Review, 2002, 67 (1): 29-47; Jasmine Van Daele, “"Engineering social peace": networks, ideas, and the founding of the International Labour Organization', Intern. Rev. Soc. Hist., 2005, 50 (3): 435-66.

${ }^{22}$ John Heitmann, 'The ILO and the regulation of white lead in Britain during the interwar years: an examination of international and national campaigns in occupational health', Labour Hist. Rev., 2004,
}

69 (3): 267-84; Marcel Robert and Luigi Parmeggiani, Fifty years of international collaboration in occupational safety and health: ILO, 1919-1969, CIS information sheet 19, Geneva, International Occupational Safety and Health Information Centre, 1969; Luigi Carozzi, 'The International Labour Organization and the health of the worker', typescript, Geneva, Switzerland, 23 Feb. 1935, 6, Folder: Propaganda pamphlet (unpublished); Hygiene, Industrial (1920-1953), International Labour Organization Archives, Geneva, Switzerland; International Labour Office, Occupation and health: encyclopedia of hygiene, pathology, and social welfare, 2 vols, Geneva, International Labour Office, 1930-1934. 


\section{Christopher C Sellers}

of the industrial worker', but none on housing or water supply. By the same token, its discussion of "industrial wastes" was devoted largely to the impact of "organic matter". It made mention of "compounds of arsenic, lead or phenol derivatives", but only to say that "waste water" should "not contain" them. ${ }^{23}$ Such discrepancies in past versus present sciences of lead's hazards raise additional questions: for instance, whether and to what extent was lead recognized in this period as an industrial water pollutant?

On this and other questions, further clarity about the ILO's version of the "global" comes when we shift our sights down the scale to what was happening in particular nations. The ILO had limited influence on industrial hygiene in the United States, the world's largest lead producer - the China of the early twentieth century. The US was also a nation whose unions were arguably weaker and less politically effective than those in many parts of Europe. By comparison with that continent, American state-building in industrial health had developed more slowly and hesitantly, and was far more decentralized. Significantly, America's lead industries (like those of China a century later) grew less because of multinationals moving in from abroad than through indigenous corporate growth.

Early American hygienists, like Alice Hamilton for example, brought to bear their own perceptions of factory conditions worldwide in making workplace lead and its effects more publicly visible within the United States. Drawing on the literature and experience of other developed nations across the Atlantic, they challenged prevalent combinations of supervision and indifference in their own country: factory inspectors, American doctors, managers and owners who believed American factories and workers to be immune from European ills. By the 1920s the "good progress" of American hygienists, based on a strengthening combination of factory and workers' compensation laws, won them entry to the ILO's circle of international experts. But continental Europeans, in particular, predominated in the authorship of the ILO's first encyclopaedia. Despite lobbying by Samuel Gompers of the American Federation of Labor and others, the US refused to apply for ILO membership until the 1930s. ${ }^{24}$ Moreover, American states adopted ILO conventions only fitfully. Some provided compensation for lead poisoning, others did not; none of them went so far as to ban white lead in paint. An abundance of lead came coupled with what, by ILO standards, was a relatively weak and porous regulatory system. Situating the ILO's international model against such national experiences emphasizes, among other things, how much the ILO's "global" knowledge and prescriptions may have been gauged to the national politics and states, as well as the levels of lead exposure, that were more prevalent in Europe than in the United States. $^{25}$

\footnotetext{
${ }^{23}$ Occupation and health, 'Homework', pp. 964-70; 'Industrial waste water (treatment of)', pp. 41-9.

${ }^{24}$ Christopher C Sellers, Hazards of the job: from industrial disease to environmental health science, Chapel Hill, University of North Carolina Press, 1997; Valentine Jobst III, 'The United States and international labor conventions', Am. J. Int. Law, 1938, 32 (1): 135-8; C J Ratzlaff, 'The International Labor Organization of the League of Nations: its significance to the United States', Am. Econ. Rev., 1932, 22 (3): 447-61.
}

\footnotetext{
${ }^{25}$ Workmen's compensation for occupational diseases: partial revision of the Convention [...]. Report V. International Labour Conference, eighteenth session, Geneva, 1934, Geneva, International Labour Office, 1933-1934; Factory inspection: historical development and present organisation in certain countries, Geneva, International Labour Office, 1923; Ludwig Teleky, History of factory and mine hygiene, New York, Columbia University Press, 1948; analysis implicitly from Sellers, op. cit., note 24 above, esp. pp. 153-72.
} 


\section{Cross-nationalizing the History of Industrial Hazard}

Industrial hazards in the developing world remained marginal not just to the ILO's vision but also to that of American hygienists during this period. To chart this marginality, we also need to reach down to individual firms and the local level. While some lead-using firms and factories were subjected to American industrial hygienists' scrutiny, others were not. Particularly marginalized were those in the most rural and undeveloped, as well as the least "American", corners of the nation. Few lead smelters were less seen by the American state and its professional companions than one built in 1887 just outside El Paso, Texas, by Phelps Dodge. Taking advantage of lead mines in northern Mexico, it lay not a hundred yards from the Mexican border, just across the river from the Mexican town of Cuidad Juárez. ${ }^{26}$ Although Alice Hamilton visited smelters in Arizona and Missouri, she did not travel as far as the most "remote" of American smelters. It seems likely that Phelps Dodge workers in El Paso were like those found in the Missouri smelter Hamilton did visit: "full of malaria, hookworm, and silica dust, from the chat heaps, to say nothing of lead". By the early 1930s, the state in which it arose still had no workers' compensation law for lead poisoning. ${ }^{27}$ The continued exclusion of this El Paso smelter from regulatory regimes that were standard in other American states suggests an intra-national and regional race to the bottom in early twentieth-century America that anticipated the cross-national migrations of industrial hazards later on.

The example of the El Paso smelter throws light on the industrial hygienists' working assumptions in this period about a certain level and style of urbanization. In Chicago, where Hamilton began her work, a city health department tackled issues of sanitation, housing and sewage, not to mention smoke, justifying industrial hygiene's confinement to factory interiors. But along the Mexico-US border, a place like "Smeltertown" (Figure 3) right beside the El Paso smelter was subject to a steady barrage of lead and other fumes from its smokestack with little or no intervention from any local health officer. We know from later studies that exposure in and around these homes could easily reach those in many parts of the plant. ${ }^{28}$

\footnotetext{
26 'ASARCO Ray Complex', http://www.asarco. com/elpasoj.html; John W Drexler, A study on the source of anomalous lead and arsenic concentrations in soils from the El Paso community-El Paso, Texas, accessed 6 June 2008 at http://www.epa.gov/ region6/6sf/pdffiles/finalreport.pdf; Isaac Frederick Marcosson, Metal magic: the story of the American Smelting \& Refining Company, New York, Farrar, Straus, 1949.

${ }^{27}$ Alice Hamilton, Exploring the dangerous trades: the autobiography of Alice Hamilton, M.D., Boston, MA, Northeastern University Press, 1985, on p. 146; idem, 'Lead poisoning in the smelting and refining of lead', Washington, Government Printing Office, 1914, United States Department of Labor, Bureau of Labor Statistics. Industrial Accidents and Hygiene Series, Bulletin no. 141; Workmen's compensation for occupational diseases, op. cit., note 25 above, p. 182.

${ }^{28}$ Hamilton, Exploring the dangerous trades, op. cit., note 27 above, for example, pp. 97-100;
}

\begin{abstract}
P J Landrigan, S H Gehlbach, B F Rosenblum, J M Shoults, et al., 'Epidemic lead absorption near an ore smelter: the role of particulate lead', N. Engl. J. Med., 1975, 292 (3): 123-9; B Raquel Ordóñez, L Ruiz Romero and I R Mora, 'Investigación epidemiológica sobre niveles de plomo en la población infantil y en el medio ambiente domiciliario de Ciudad Juárez, Chihuahua, en relación con una fundición de El Paso, Texas', [Epidemiological study of lead levels in the child population and the household environment in Ciudad Juárez, Chihuahua, Mexico, as compared to a foundry area in el Paso, Texas], Boletín de la Oficina Sanitaria Panamericana, 1976, 80 (4): 303-17; also the impetus for the first study came from a collaboration between the Centers for Disease Control and local health department officials: see reprint of the initial 1973 study in 'Epidemiologic notes and reports human lead absorption-Texas', accessed 6 June 2008 at http://www.cdc.gov.ezproxy. hsclib.sunysb.edu/mmwr/preview/mmwrhtml/ 00049347.htm.
\end{abstract}




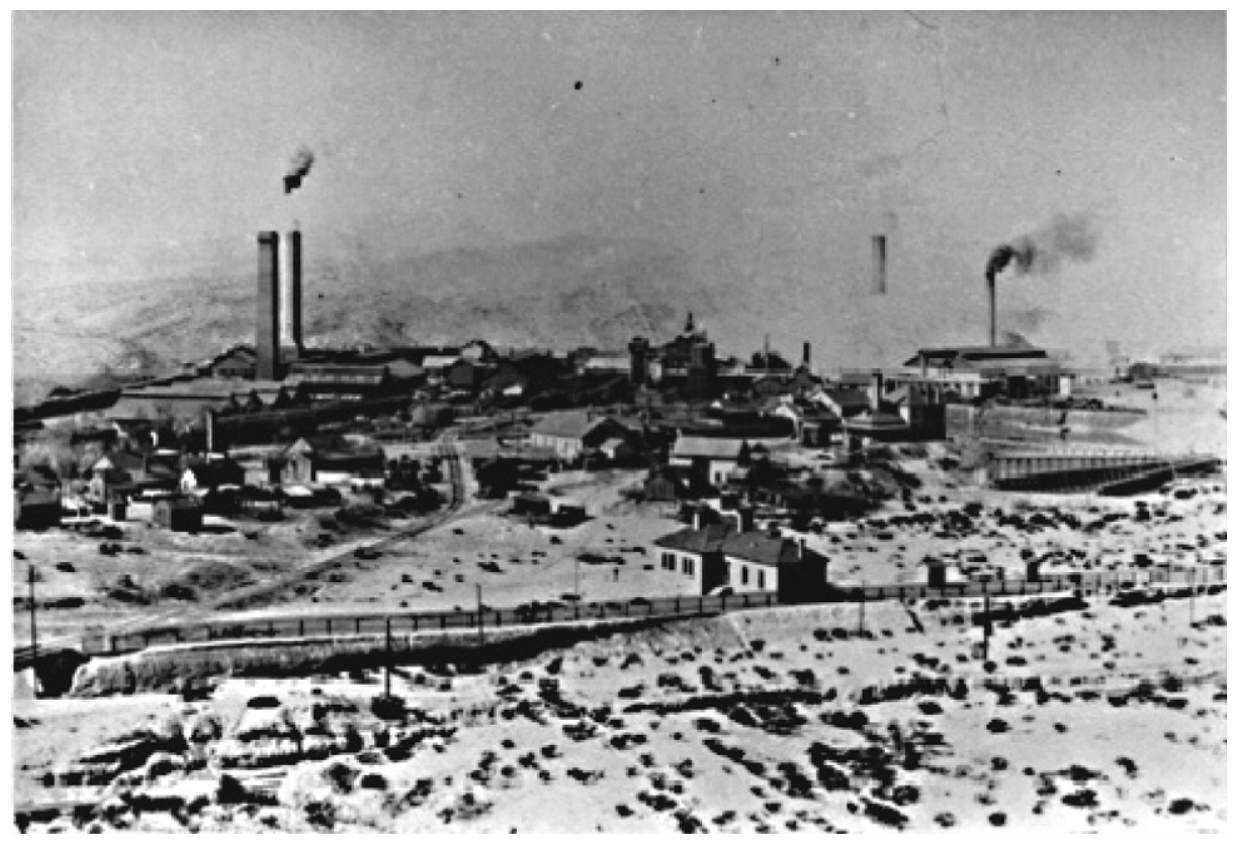

Figure 3: The El Paso smelter and vicinity, circa 1889.

(Source: http://dmc.utep.edu/ oralh/GIFS/smelter.gif)

Finally, levels of lead pollution across the border in Mexico reveal assumptions about industrialization that further blinkered American hygienists to lead's actual course through their own as well as this neighbouring nation. By the early 1930s, although American capital had funded an industrial level of mining and smeltering in Mexico, many uses of lead remained closer to a craft industry with which the professional hygienists, whether in America or Europe, rarely bothered. In villages of southern Mexico, thousands of families earned a living through pottery production that relied on leaded glazes for colour. Few uses of lead were more traditional than this, in which work exposures were barely separated from those inside the home. Most of their small open kilns lay within home lots. Interestingly, relatively recent studies of these family potting enterprises find that both children and adults get their biggest doses of lead from the food cooked in their leaded pots. ${ }^{29}$

\footnotetext{
${ }^{29}$ George M Foster, 'The folk economy of rural Mexico with special reference to marketing', $J$. Marketing, 1948, 13 (2): 153-62; Paul Taylor, 'Making cántaros at San José Tateposco, Jalisco, Mexico', American Anthropologist, 1933, 35 (4): 745-51; E B Sayles, 'Three Mexican crafts', American Anthropologist, 1955, n.s. 57 (5): 953-73; G Molina-Ballesteros, M A Zuñiga-Charles, J E García-de Alba, A Cárdenas-Ortega and
}

P Solis-Camara, 'Lead exposure in two pottery handicraft populations', Archivos de Investigación Médica, 1980, 11 (1): 147-54; R Hibbert, Zhipeng Bai, Jaime Navia, Daniel M Kammen and Jungeng Zhang, 'High lead exposures resulting from pottery production in a village in Michoacán State, Mexico', Journal of Exposure Analysis and Environmental Epidemiology, 1999, 9 (4): 343-51, doi:10489159. 


\section{Cross-nationalizing the History of Industrial Hazard}

We already have some sense of how turning a blind eye to these routes of exposure to lead may have shaped the global perspective of America's industrial hygienists in this period, but less of how these same people may have managed the contrasting approaches to lead during the 1930s by Mexican versus American politicians. American hygienists saw Mexico's industrial hazards as so thoroughly backward that the lead researcher Robert Kehoe went to Mexico in 1933 to establish "primitive" exposure levels. In tiny mountain villages around Ixtlahuaca, he sought a contrast with those he had measured for nonoccupational exposures in American cities. Among a population eating out of lead-glazed pots, he surmised he was finding a pre-industrial "normal" lead level. ${ }^{30}$ Ironically, however, the worker and peasant friendly regime of Lázaro Cárdenas had soon gone much further than the American New Dealers by making those lead-related "conventions" recommended by the ILO legally enforceable. In 1934, lead poisoning became compensable nationwide, something that only America's most industrial states had done. Some four years later the Mexican national government passed a convention that never made it past any legislature in the US, outlawing white lead paint in interiors. ${ }^{31}$

Around this same time, change was afoot in the global vision of the ILO (which the US finally joined in 1934). Gradually, it began turning more attention to the problem of industrial hygiene in the developing world. Carozzi initiated the ILO's first survey of what would become, post-1945, another central emphasis: the importance of training programmes in industrial medicine and hygiene. Compensation for a disease like lead poisoning, after all, arguably meant little if there were no knowledgeable eyes to recognize or confirm it; not surprisingly, there were far more such programmes in the US than anywhere in Latin America. Starting with a consultation visit to Egypt in 1938, Carozzi inaugurated after the war a scheme that sought to address the dearth of expertise and other peculiar dilemmas plaguing the workplaces of non-European and less developed nations. ${ }^{32}$ In taking up this initiative, the ILO was joined by other post-Second World War international institutions, notably the World Health Organization. Simultaneously, changes in the knowledge and regulation of toxins such as lead, centred in places like the United States, bred new crossnational contrasts in approach, as well as actual exposures, to industrial hazards.

\section{The Uneven Development of Post-war Precautionism}

Most historical work on the more aggressive approaches to lead regulation that emerged after the Second World War has confined itself to events within the scholars' own nations.

\footnotetext{
${ }^{30}$ Robert A Kehoe, Frederick Thamann and J Cholak, 'On the normal absorption and excretion of lead. I. Lead absorption and excretion in primitive life', Journal of Industrial Hygiene, 1933, 15 (5): 257-72; in fairness to Kehoe's team, they did note and try to measure the influence of lead-glazed pottery.

${ }^{31}$ See entries for "Mexico" accessed 11 June 2008 at 'ILOLEX: country information', http://www.ilo. org/ilolex/english/newcountryframeE.htm.

${ }^{32}$ Luigi Carozzi, 'Training in industrial medicine', International Labour Review, 1939, 40 (6): 733-67;
}

\author{
Luigi Carozzi and others, 'Folder: Industrial Hygiene \\ Egypt-Collaboration of ILO Official with PH \\ Authorities', correspondence, Industrial Hygiene, \\ International Labour Organization Archives. The ILO \\ had already become involved with developing-world \\ colonies in other ways, as with a South African \\ pneumoconiosis conference; International Labour \\ Office, Silicosis: records of the International \\ Conference held at Johannesburg, 13-27 August, \\ 1930, Studies and Reports No. 13, series F, Industrial \\ hygiene, Geneva, International Labour Office, \\ 1930.
}




\section{Christopher C Sellers}

The recent burst of American scholarship shows how a more cautious approach to lead unfolded that took a special interest in exposure not connected with the workplace; what became known as the "environment". The chief concern was now the exposure to lead pollution of consumers and populations outside industrial plants, from peeling lead paint to the burning of tetraethyl lead in petrol. ${ }^{33}$ Among the scientific changes ushering in this new awareness from the 1950s into the 1970s, were the ever more subtle and long-term effects of lead poisoning, especially among children, that caused behavioural disturbances, slowed nerve conduction and lowered IQs. Scrutiny of lead levels in places where no one lived, such as the Greenland ice shelf, also showed pre-industrial lead exposures turned out to be several times lower than what Kehoe had found in his Mexicans. ${ }^{34}$ Changes in lead science and regulation in the post-Second World War US owed much to the rise of a federal and academic research establishment devoted to chronic degenerative ailments such as cancer and heart disease, now widely recognized as the primary killers of Americans. Public funding sources for research into lead and other industrial and environmental hazards replaced an earlier reliance on corporate funding, exemplified by Kehoe. After innovations in epidemiology and toxicology helped to establish why a higher level of protection was necessary, new federal laws and regulation took on a much wider range of consumer and environmental hazards, from food additives to cigarettes to industrial pollution. ${ }^{35}$ While we are now learning about the history of this precautionism within particular nations like the United States, the cross-national dynamics that also drove or facilitated its advent have received less attention. As with the preceding period, study of the global visions of the time, like that of the ILO, may reveal much; so too, that of carefully selected local sites.

Among the expedients turning many nations towards precautionary measures over the post-war period was the widespread adoption of the Maximum Allowable Concentration (MAC) levels by industrial hygienists. This strategy, first used in a tentative way by French, German and English investigators, came to full fruition in the industrial hygiene circles of the United States (as well as the Soviet Union) during the 1930s and 1940s. ${ }^{36}$ It reflected a growing confidence in the ability of engineers to monitor and control the atmospheric concentration of toxic dust such as lead, rather than waiting until workers actually became sick. MAC levels represented not so much an abandonment of the threshold idea, embedded in the clinical distinction between lead absorption and poisoning, as its formalization.

\footnotetext{
${ }^{33}$ Christian Warren, Brush with death: a social history of lead poisoning, Baltimore, MD, Johns Hopkins University Press, 2000; David Rosner and Gerald Markowitz, Deceit and denial: the deadly politics of industrial pollution, Berkeley, University of California Press, 2002; Peter C English, Old paint: a medical history of childhood lead-paint poisoning in the United States to 1980, New Brunswick, NJ, Rutgers University Press, 2001.

${ }^{34} \mathrm{C}$ C Patterson, 'Contaminated and natural lead environments of man', Arch. Environ. Health, Sept. 1965, 11: 344-60.

${ }^{35}$ An early confrontation came at United States Public Health Service, Symposium on environmental lead contamination, vol. 1440, Public Health Service
}

\author{
Publication, Washington, DC, US Department of \\ Health, Education, and Welfare, Public Health \\ Service, 1966. \\ ${ }^{36}$ On early uses by French, German and English, \\ see 'Air-testing in workshops', pp. 81-9, in \\ International Labour Office, Occupation and health, \\ op. cit., note 22 above. On American conversion of \\ MAC levels into a systematic tool, see Christopher \\ Sellers, "A prejudice that may cloud the mentality": \\ making objectivity in early twentieth century \\ occupational health', in John W Ward and Christian \\ Warren (eds), Silent victories: the history and practice \\ of public health in twentieth-century America, \\ Oxford and New York, Oxford University Press, \\ 2007.
}


Broaching the possibility that clinical poisoning could indeed be avoided, MACs opened the door to still more preventive approaches. American professionals started compiling entire "standard" lists of MAC levels for most workplace hazards, even before the Second World War. We have much to learn about how the US and many other countries set about adopting their own lists of MAC levels, as well as how the ILO and WHO sought to harmonize these approaches into a single international standard.$^{37}$ One driver of change appears to have been the Cold War, which yielded a stark contrast in the way lead hazards were studied on opposite sides of the Iron Curtain. From the first use of MACs in the 1940s, Americans, following epidemiological and clinical studies by the United States Public Health Service, set their tolerance levels for lead dust where clinical symptoms started to occur. The Russians led their Eastern European allies in urging stricter standards, more like those in the Americans' regulation of food additives, based on toxicological experiments on animals. Despite American dismissals of post-war Russian research claims as propaganda (and the lack of pollution control in the factories of Russia and Eastern Europe), these turned out to be a precise prediction of where US lead research would go during the 1960s and 1970 s in its "effects ... on ... higher nervous activity". 38

Although these international debates over lead science and regulation were no doubt important, a comparison between developed and less developed nations at border-straddling industrial locales, like the El Paso smelter, can uncover a great deal about the differing roots and implications of the new precautionism. While the science moved beyond the worker epidemiology underpinning the early MAC levels, it did not focus solely on consumer exposure to deleterious substances such as tobacco. Long-neglected or under-regulated factories such as El Paso's lead smelter served as pivotal sites for forging a new environmental epidemiology of resident populations. When Philip Landrigan, a paediatrician working for the Centers for Disease Control, travelled to Smeltertown and vicinity in 1971, most of the previous investigation of childhood lead poisoning had taken place in the interiors of cities like Baltimore. Undertaking detailed environmental and clinical study of lead exposures in the community surrounding the factory, Landrigan and his colleagues measured routes and concentrations of lead and compared these with levels of lead in the blood of neighbourhood children. They found strong, statistically significant correlations between lead exposure and blood levels of more than 40 micrograms per decilitre. Also administering several neurological assessments, from finger-wrist tapping to IQ tests, they established similar strong connections between this level of absorption and brain or nerve impairment.

\footnotetext{
${ }^{37}$ International Union of Pure and Applied Chemistry, Proceedings of the International Symposium on maximum allowable concentrations of toxic substances in industry, held in Prague, Czechoslovakia, April 1959, London, Butterworths, 1961; Permanent Commission and International Association on Occupational Health, and International Union of Pure and Applied Chemistry, Symposium international sur les limites tolérables pour les substances toxiques dans l'industrie; comptes-rendus; IIeme, Paris 1er Avril-6 Avril 1963, Paris, Institut National de Securité, 1965; Joint ILO/WHO Committee on Occupational Health, Permissible levels of toxic substances in the working environment;
}

6th Session of the Joint ILO/WHO Committee on Occupational Health, Geneva, 4-10 June 1968, vol. 20, Occupational Safety and Health Series, Geneva, International Labour Office, 1970.

${ }^{38}$ E I Lyublina, 'Some methods used in establishing the maximum allowable concentrations', in International Union of Pure and Applied Chemistry, Proceedings of the International Symposium on Maximum allowable Concentrations of Toxic Substances in Industry, held in Prague, Czechoslovakia, April 1959, International Labour Office, Encyclopedia of occupational health and safety, Geneva, ILO, 1971, quotations on pp. 113, 109, 110. 


\section{Christopher C Sellers}

This study was cited as providing some of the most conclusive evidence for the dropping of lead levels of the late 1970s for workplace as well as outdoor air. ${ }^{39}$

A look at the local history, not just of this factory but of its surrounding environment, illustrates how much more was at work in this new precautionism than simply professional and scientific change. What enabled the new laws, agencies and funding that fuelled caution regarding lead and other hazards was not just new science but a groundswell of public disquiet about industrial pollution. While labour unions and work stoppages played a role in this explosion of concern in the US, it flourished especially among those living in the suburbs. ${ }^{40}$ Trends in the larger county where the El Paso smelter was located point to widespread changes in urbanization that facilitated the avoidance of polluted areas: it had become possible to live as well as work at a comfortable, more salubrious remove from such industrial plants. Over the post-war period, the well-to-do inhabitants of El Paso moved away from the factory area. Smeltertown itself came to be inhabited by mainly lower income families of Hispanic origin, whose breadwinners dominated the smelter's workforce. Those moving to the suburbs were mostly wealthy and white, and unlikely to do smelter work. The new public support for precautionism reflected an evolving urban geography in the post-Second World War United States, marked by contrasts in ethnicity or race, occupation, and wealth, which held out the possibility of total escape from the factory (see Figure 4). Of course, in a place like El Paso, industrial pollution also denied it, by finding its way into the whiter and wealthier suburbs. The Landrigan study was triggered by just such exposures and their political repercussions. ${ }^{41}$ Today the model for industrial pollution depicted on the Environmental Protection Agency (EPA) website captures this "post-industrial" detachment from the factory in an idealized form (see Figure 5). Nobody works or lives around these polluting factories; everyone lives and works across the river. Here the provision of running water, flush toilets, and water treatment, those sanitary amenities pushed by earlier generations of health authorities, are taken for granted.

If these local urbanizing trends undergirded this new precautionism on the American side of the border, trends in industrialization took the Mexican side in a quite different direction. On a global scale, factories had begun migrating from developed nations like the United States to developing countries like Mexico. The Mattel Corporation itself offers a nice example. Begun in the Los Angeles area just after the Second World War, by the early 1960s its southern California factories had undergone crippling strikes, and it was in search of new factory settings. Among the first American companies to establish a factory in China, Mattel also turned to Mexico, whose government in 1965 set up tariff-free zones for American companies just south of the US border. While Mattel and other toy makers chose

\footnotetext{
${ }^{39}$ Landrigan, et al., op. cit., note 28 above; P J Landrigan, E L Baker Jr, R G Feldman, D H Cox, et al., 'Increased lead absorption with anemia and slowed nerve conduction in children near a lead smelter', J. Pediatrics, 1976, 89 (6): 904-10; National Institute for Occupational Safety and Health, Occupational exposure to Inorganic lead: revised criteria, 1978, vol. 78, DHEW (NIOSH) publication [Cincinnati], US Department of Health, Education, and Welfare, Public Health Service, Center for Disease Control, National
}

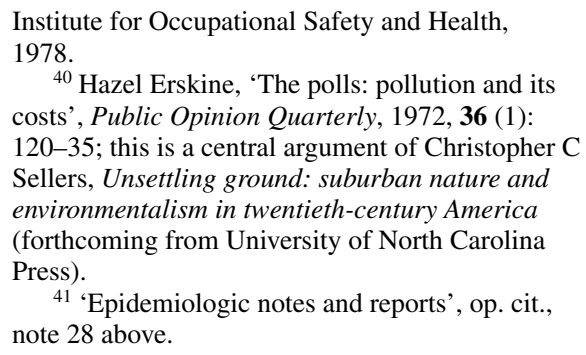




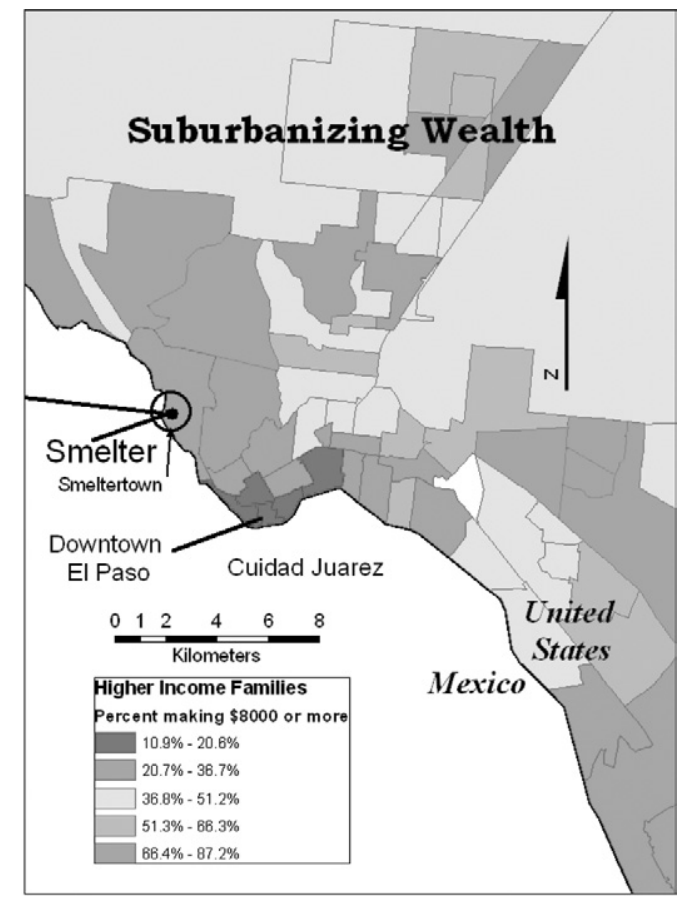

Figure 4: Higher income families by census tract, 1970, in the El Paso area. Wealthier residents, who moved away from the smelter, also tended to be white rather than Hispanic, and to work in professional and managerial positions.

(Data Source: http://www.nhgis.org/ map by Christopher Sellers.)

Tijuana, helping to install in it the biggest concentration of these maquiladora operations, El Paso's neighbour, Ciudad Juárez, was next in line by 1986, with nearly two hundred.

With this industrialization came an urbanization of quite different intensity and character from that on the American side. Whereas between 1940 and 1980, El Paso grew fivefold, Ciudad Juárez, on the other side of the Rio Grande, expanded twenty-fivefold. As the EPA was created in the States and began to implement new federal environmental policies, Cuidad Juárez's population growth was rapidly outstripping that of El Paso, to attain nearly half a million by 1980. Along with Tijuana just south of San Diego, where Mattel's biggest Mexican operation lay, these cities emerged as Mexico's biggest industrial metropolises outside Mexico City. ${ }^{42}$ The pattern of city growth contrasted even more starkly with that on

\footnotetext{
${ }^{42}$ Louise Story, 'After stumbling, Mattel cracks down in China', New York Times, 29 Aug. 2007, accessed 7 June 2008 at http://www.nytimes.com/ 2007/08/29/business/worldbusiness/29mattel.html; Tim Golden, 'New ball game for Mexican toys', New York Times, 28 Aug. 1992, accessed 8 June 2008 at http://www.nytimes.com/1992/08/28/business/newball-game-for-mexican-toys.html; Philip L Martin, 'Foreign direct investment and migration: the case of
}

Mexican maquiladoras', International Migration, 1992, 30 (3-4): 399-422; Paul Cooney, 'The Mexican crisis and the maquiladora boom: a paradox of development or the logic of neoliberalism?', Latin American Perspectives, 2001, 28 (3): 55-83; Timothy C Brown, 'The fourth member of NAFTA: the U.S.-Mexico Border', Annals of the American Academy of Political and Social Science, 1997, 550: 105-21. 


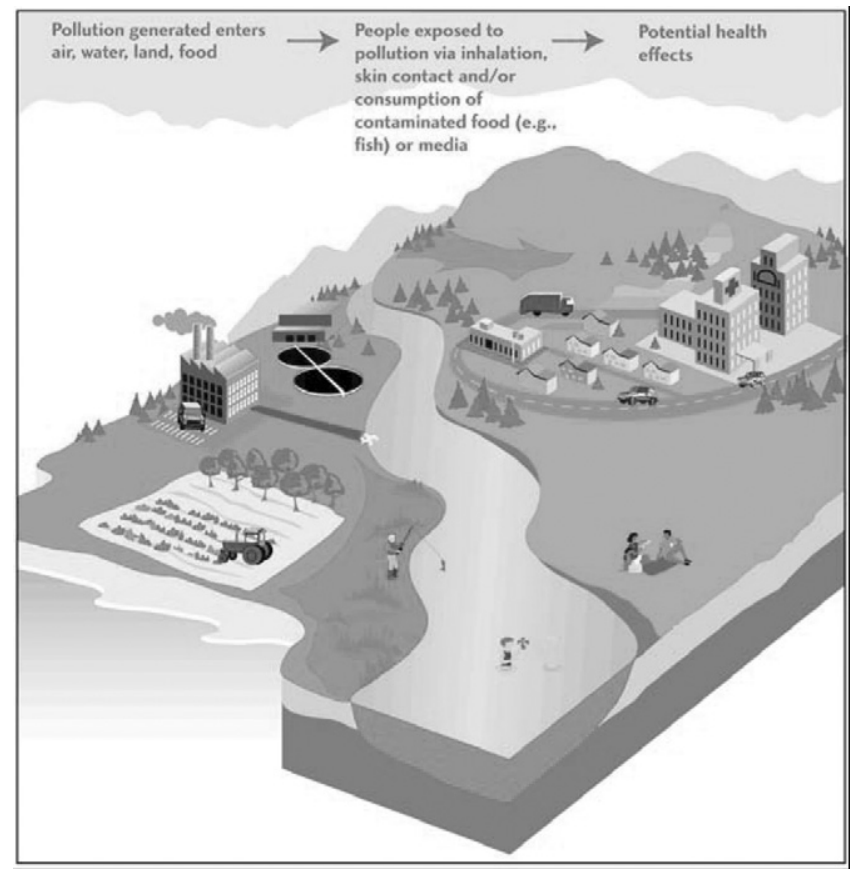

Figure 5: Idealized depiction on the EPA website, 2004. The factory and other sources of pollution lie across the river from all depicted residences.

(Source: http://www.epa.gov/indicate/roe/pdf/EPA_Draft_ROE.pdf)

the American side of the border, where precautionist science and principles had begun to flourish. Instead of moving further from Smeltertown, like the inhabitants of El Paso, newcomers living in and around Ciudad Juárez crowded closer in. Just across from the factory there emerged one of the colonias through which Cuidad Juárez and other Mexican towns grew. An aerial photo from 1982 shows a stark contrast with the suburban neighbourhoods and other settlements to the north, with small houses and bare yards, without lawns.

These contexts suggest reasons why precautionism was taken up more slowly in Mexico than in the US, even as the exposures highlighted by the new environmental science were indeed worse. By the 1970s, Mexican health experts had undertaken studies of their own on environmental lead pollution, which duplicated Landrigan's epidemiological approach. Their investigation was smaller, with no accompanying neurological studies. Yet they found more children at risk, including 52 per cent of those within a mile of the smelter. ${ }^{43}$ That the lead exposures were correspondingly more massive was, in part, a reflection of settlement patterns that brought many more children into closer range of the plant. Mexican public

\footnotetext{
${ }^{43}$ Smeltertown map accessed 9 May 2010 at http://www.lib.utexas.edu/maps/us_mexico_border/ txu_oclc_13545561_085. Jorge Morales, 'History of the National Federation of Occupational Health (FeNaSTAC), Mexico', in Antonio Grieco (ed.),
}

Origins of occupational health associations in the world, Amsterdam, Elsevier, 2003, esp. pp. 124-5; Ordóñez, Ruiz Romero and Mora, op. cit., note 28 above. 


\section{Cross-nationalizing the History of Industrial Hazard}

health officials in towns like Juárez nevertheless faced more difficult choices than their American counterparts, for lead poisoning was not the only or even the most dangerous health threat to those living in places like the colonias. As early as 1977, the New York Times was reporting "hordes of squatters" on Juárez's “outskirts", including families with children. In addition to dirty air, many of these houses were also without the sanitary safeguards like running water and flush toilets that Americans largely took for granted. Sewage ran through open channels beside the streets. Monitoring of the water supply for bacteria only began in the 1990s on the Mexican side, and hepatitis and tuberculosis remained constant problems. ${ }^{44}$

Although the new precautionist experts and regulations to the north furnished their Mexican counterparts with ready-made methodologies and remedies, they faced additional dilemmas that did not trouble American precautionists. For instance, following US as well as other international examples, Mexico's federal government inaugurated a shift away from leaded petrol in 1986. By 1998 lead had been eliminated from all petrol sold in the Mexico City area, and mean aerial lead levels were plummeting. Yet the ways in which Mexico's national oil company Pemex reformulated petrol to take the lead out combined with this mega-city's predominantly older car fleet to exacerbate other kinds of air pollution, notably from ozone. In the realm of lead, as well, Mexico's would-be precautionists still confronted an array of endemic exposures that their American counterparts did not. Forty per cent of families living in the metropolis still used lead-glazed ceramics. Outside the city, not only is pottery usage still more pervasive, rising tourism has enabled 1.5 million Mexican families to continue to rely on family kilns for income. ${ }^{45}$

By 2007, when the story of Mattel's toxic toys erupted, it is a safe, if ironic, bet that the biggest impact of precautionist measures in Mexico was probably in Mattel's plant in Tijuana. Since the company shut down its last plant in the United States in 2002, its testing facilities for what it sells there have been confined to this south-of-the-border factory, to which the China-made goods still in its American warehouses were shipped once the story of contamination broke. In Mexico City, meanwhile, consumer testing of toys by the national government began only in 1994, nearly two decades after Mattel arrived in Tijuana. ${ }^{46}$ And when it comes to toys, the Mexican consumer agency, unlike its American and European counterparts, faces another level of dilemma: a huge market of native-made knock-offs or

44 'El Paso smelter still poses lead-poisoning peril to children in Juárez', New York Times, 28 Nov. 1977, accessed at 8 June 2008 at http:// select.nytimes.com/gst/abstract.html?res= F20E10FC345B1A7B93CAAB178AD95F438785F9; Roberto Suro, 'Border boom's dirty residue imperils U.S.-Mexico Trade', New York Times, 31 March 1991, accessed 6 June 2008 at http:// www.nytimes.com/ 1991/03/31/us/border-boom-sdirty-residue-imperils-us-mexico- trade.html; Brown, op. cit., note 42 above.

${ }^{45}$ Lourdes Schnaas, S J Rothenberg, M F Flores, S Martínez, et al., 'Blood lead secular trend in a cohort of children in Mexico City (1987-2002)', Environ. Health Perspect., 2004, 112 (10): 1110-15; Marlene Cortez-Lugo, Marta $\mathrm{M}^{\mathrm{a}}$ Téllez Rojo, Héctor Gómez Dantés, Mauricio Hernández-Avila, 'Tendencia de los niveles de plomo en la atmósfera de la zona metropolitana de la Ciudad de México, 1988-1998'

['Trends in atmospheric concentrations of lead in the metropolitan area of Mexico city, 1988-1998'], Salud Pública de México, 2003, 45 (Suppl 2): S196-202; $\mathrm{H}$ A Bravo and R J Torres, 'The usefulness of air quality monitoring and air quality impact studies before the introduction of reformulated gasolines in developing countries: Mexico City, a real case study', Atmospheric Environment, 2000, 34 (3): 499-506; Working Group III, 'Ceramic glazes', in Christopher P Howson, Mauricio Hernández-Avila and David P Rall (eds), Lead in the Americas: a call for action, Washington, DC, Committee to Reduce Lead Exposure in the Americas, Board on International Health, Institute of Medicine, in collaboration with the National Institute of Public Health, 1996, p. 129.

${ }^{46}$ Story, 'After stumbling, Mattel cracks down in China' "Mexico" in Table 'Toy Safety Standards around the World' accessed 26 February 2010 at http://www.toy-icti.org/info/toysafetystandards.html. 


\section{Christopher C Sellers}

contraband. Nearly half the toys sold are illegal, hence not reachable even by increased testing. Those toys that Mattel laboratories reject for their lead content may well wind up being sold by unlicensed street-side vendors. ${ }^{47}$

We Americans and Europeans have come to precautionism only through decades, even a century, of institutional development in our governments and professions, also more quietly, in our formal private economy. In America, a new self-described "environmental" or "ecological" approach to industrial hazards coalesced hand in hand with the transformation of American cities, homes and jobs, which enabled people to imagine factories, as well as public health interventions like DDT, as doing more harm than good. No doubt there were, and still are, corners of America and Europe untouched by precautionism, where the more subtle risks of lead exposure are ignored or sloughed off. But more dramatic differences in how lead is seen and interpreted-as well as actually distributed-are to be found across a nation such as Mexico. Here, as in many parts of the developing world, experts and advocates not only confront a greater magnitude and variety of lead hazards, these come piled on top of others, including sanitary ones their US counterparts have long since faced and "conquered". In Ciudad Juárez, industrial and childhood lead poisoning have multiplied, and become recognized, hand in hand with water-borne infections. There, as in Mexico City, lead exposure has proved difficult to tame by those measures that worked in the United States. Where, by best-guess projection, lead's human contacts remain so much more pervasive and persistent, the popular as well as medical cultures of lead cannot but be different from those in the States.

\section{Conclusions}

Study of the genesis of these differences offers many engaging possibilities for medical, health and other historians. We may, for instance, shed light on resistances to public health interventions with which health activists have been confronted in a place such as Mexico. Studies by public health educators tend to shout their bias towards the final "stage" they envision: where western experts themselves have wound up. ${ }^{48}$

A more robust attunement to cultural as well as environmental differences, and the longer historical contrasts that lie behind them, may help us better understand those popular categories through which lead and levels of exposure to it are understood. With such an understanding may come further appreciation of what may stand in the way of inculcating a more modern lead ontology, those categories, values and contexts that stir active resistance to the health educators' messages. What seems clear is that the opposition and scepticism faced by Mexican advocates runs deeper than the resistance of multinational corporations, or the mistaken beliefs pinpointed by health educators. Our own "modern" prescriptions for lead reach into what many Mexicans see as new economic opportunities, but also into traditional spheres of knowledge and practice. Either way, they implicate ways

\footnotetext{
${ }^{47}$ Diego Cevallas, 'Latin America: careful with the toys', IPS News (August 30, 2007) accessed 26 February 2010 at http://ipsnews.net/ news.asp?idnews $=39080$

${ }^{48}$ See for instance table 'Seven Stages of Community Perception of Lead as a Health Risk,
}

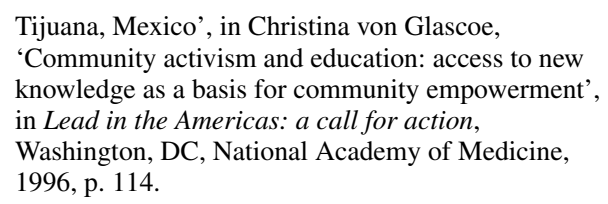




\section{Cross-nationalizing the History of Industrial Hazard}

of life and livelihood that are not, or are no longer shared by most Americans and western Europeans.

Along this and other fronts, the cross-national study of industrial hazards has much to offer, in part because of how manageable it has become. Innovations not just from history of science and of medicine but from labour and business, environmental and urban history, as well as several decades of environmental science, have facilitated very different encounters with lead and other toxins on the same analytical and historical page. If we are willing to range across the available intellectual registers, to strive after an environmental as well as a socio-cultural symmetry in our analysis, we can understand simultaneous trajectories of nations as different as the US and Mexico in comparable terms. We thereby also begin to fathom precisely how asymmetrical their trajectories have been. Differing histories of the engineering as well as the control of lead's flows and exposures underpin contrasting ontologies of lead and its effects in these two nations. Central to the achievement of footloose firms like Mattel has been their ability to extract profit from such cross-national differences in the ontology of toxins like lead, while keeping their own hands relatively clean. Until very recently, perhaps.

Through the last few decades, the flight of factories and industrial production from the developed to the developing nations has reshaped our world, but also subtly warped how medical and other historians have seen it. Simply by tackling this important subject, we join many other scholars in helping to puncture the conceit that ours is a "post-industrial society". What is such a notion, if not an excuse for developed-world scholars to avert our eyes from our continuing dependencies on production elsewhere? Within the scholarship that challenges such ideas, historians of health and medicine, as well as the environment, have an especially critical role to play. We come intellectually armed to bring out what many other scholars have tended to neglect: that this historical shift in the geography of industry has had human bodily as well as ecological consequences. Among the rewards in taking on historical contrasts as marked as those between the United States and Mexico, is the deeper and broader understanding of what has enabled health advances in a nation such as the United States itself. Through such comparisons, the underlying conditions for public health victories like that of America's precautionists over lead-from the human capital of expertise, the eradication of pre-existing "traditional" materials and practices, the peculiar style of post-Second World War urbanization-stand out precisely because of their relative absence in a places like Mexico, where precautionists have had a considerably harder time.

In order to plumb the gravity and implications of such a topic we cannot, however, afford to be sceptical about the various sciences of lead that have emerged across time and place; on what the dangers of lead are, we must take ontological sides. After all, what appeals in this, as in so many topics that today's historians choose to take up, is its moral dimensions, what historical investigation may say to our own place and time. Seeking out the transnational trail of lead in history demonstrates how, in the past as well as the present, that pathway does not stop at our own nation's borders. Such a history reinforces the message that the currents of toxins in a place like Mexico or China may continue to track back to us in the developed world who now usually imagine ourselves to be living "lead-free". When I start up my car or turn on a computer, I am not sure I will ever habitually think of a belching lead smelter or a coughing mine worker in China. But my hope is that histories that stir awareness of lead's present absence in our own lives may help to inoculate us against at least 


\section{Christopher C Sellers}

some of the indifference to which our globalizing age is prone. In an important sense, we re-connect with that smelter and those workers and their children each and every day. We do this not so much through our perception of lead, nor through any bodily hazard it poses to us, rather by reliance on the lead which they have passed our way. This common material thread also binds us to the hazards and the victims it has wrought elsewhere. Building this commonality into our histories invites a search for ways of taking responsibility for the costs it imposes, however distant and remote. 